\title{
Phyto-Tissue Culture Bank (PTCB) for Maintaining Plant Diversity
}

\author{
El-Kazzaz AA* \\ Department of Plant Biotechnology, Genetic Engineering Division, National Research Centre, Egypt
}

Submission: November 11, 2018, Published: November 29, 2018

"Corresponding author: El-Kazzaz AA, Professor of biotechnology, Department of Plant Biotechnology, Genetic Engineering Division, National Research Centre, 12622, Dokki, Giza, Egypt

\section{Short Communication}

The diversity of life forms is many, and we still have to define many of them as they form a complex biological fabric entangled of life on this planet. Plant biodiversity is very fantastic form of life forms which serves the humanity happiness. However, many forms of plant life are deteriorating and extinct for many reasons, including urbanization that does not take into account plant life in the construction sites and the construction of roads as well as the unfair harvesting of many of these plants which are important in many industries and grassing without having a new place for culture, which causes the extinction. In addition to changing the climatic conditions which play unfair role in changing the plant growing behaviour that cause the deterioration of plant diversity in its natural site [1-3].

Plant biodiversity must be dealt with all the more earnestly as a worldwide wealth, to be filed, utilized, conserved and safeguarded as true to type to the original plant source from which is taken. Traditional plant propagation techniques known to farmers are used to conserve ex situ vegetation diversity, but these methods face many barriers to natural propagation, making them unsuitable for plant conservation in a timely manner and in limited space, especially those plants that suffer from immature seeds as well as seeds and buds dormancy, non-seed or few seeds produced and also exposure to unfavorable climatic conditions or exposure to insects and pathological injuries during the propagation time.

It is known that, plant wild types form important part of plant biodiversity on the earth especially those plants that used in development of fodder plants, pharmaceuticals and many industries. Such wilds are going to be endangered and must be safeguarded.

For this purpose, the welfare solution is to use the technique of cultivating cells and tissues in the process of propagation and conservation of this plant diversity as in vitro botanical garden [4,5]. In this respect, there are near 100 botanical gardens throughout the world have the tissue culture and micropropagation facilities $[4,6]$. However, more than 400 botanical gardens throughout the world are banks of seeds preservation. As with most tissue culture systems, any plant part can be maintained and multiplied to shootlets and plantlets as true to type as most in culture by dividing and sub-culturing on appropriate fresh medium periodically under controlled aseptic conditions.

Reproduction of plants in vitro is really important for safeguard plant wilds from annihilation $[7,8]$. In vitro methods can set substitutional procedures for reproduction and preserving the plant assets in the long term for these species forming PhytoTissue Culture Bank (PTCB). In vitro propagation can provide plant stocks not only in identical forms but also certified free of pathogens of those species around the year [9-11].

Moreover, if available enough plants produced in vitro, they can be used to regenerate the existent populates for establishing novel implantations for preservation, research, education, or recreation purposes. In vitro produced plants can be marketed to compilers and that will decrease the unfair harvesting pressures on wild plants [12].

It is remarkable that, there is an acquired action worldwide for using phyto-tissue culture techniques for reproduction and conservation of endangered plants in response to the Global Strategy for Plant Conservation (GPSC) [13]. Therefore, PhytoTissue Culture Bank (PTCB) can be utilized for long when seeds or embryo banking is not possible or when conventional propagation is not useful for ex situ embalmment, furthermore, (PTCB) provides plant materials for agrarian various researches, plant cultivation in fields for minifies compressing on collecting the wild plants in nature; taxonomic, methodological, identification and confirmation research; sorts preface and recovery of habitats activities; confirmed varieties for nursery trade, local agriculture, safe agriculture, local forests, and crop breeding programs and demonstration, learning, teaching and society effectivenesses.

It is concluded from the above that, the need to use in vitro tissue culture techniques is a necessary necessity to maintain plant assets, giving an incentive to defeat these difficulties and making these strategies a fundamental piece of the ex situ 
preservation system; whereas, in vitro plants are multiplied in many folds through the multiplication process that can eventually improve and increase declining habitats of rare plant species, retrieve equalization to sensitive biological communities harmed by human and irregular impedance. It was necessary to use phytotissue culture protocols to preserve the possessed inherited plant diversity wealth from ancient times and conserve them in PhytoTissue Culture Bank (PTCB).

\section{References}

1. Hawkins B, Sharrock S, Havens K (2008) Plants and climate change: which future? Botanic Gardens Conservation International, Richmond, UK.

2. Pritchard DJ, Harrop SR (2010) A re-evaluation of the role of ex situ conservation in the face of climate change. BG journal 7(1): 3-6.

3. Wilson EO (1988) The Current State of Biological Diversity. In: Wilson EO, Peter FM (Eds.), Biodiversity. National Academy Press. Washington, USA, pp. 3-20.

4. Pence VC (2011) The possibilities and challenges of in vitro methods for conservation. Kew Bulletin 65(4): 539- 547.

5. Sarasan V, Cripps R, Ramsay MM, Atherton C, McMichen M, et al. (2006) Conservation in vitro of threatened plants--progress in the past decade. In Vitro Cell Dev Biol Plant 42(3): 206-214.

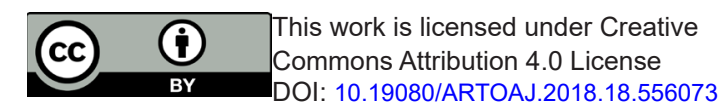

6. Pence VC (2012) From freezing to the field-in vitro methods assisting plant conservation. BG Journal 9(1): 14-17.

7. Mikulík J (1999) Propagation of endangered plant species by tissue cultures. Acta Univ. Palacki Olomuc Fac rer nat Biol 37: 27-33.

8. Kḷaviņa D, Gailìte A, Jakobsone G, ^Eçajeva J, Gavrilova Ì (2004) Tissue culture technology in conservation of threatened plant species of Latvia. Acta Universitatis Latviensis Biology 676: 183-188.

9. Fay MF (1992) Conservation of rare and endangered plants using in vitro methods. In Vitro Cell Dev Biol Plant 28(1): 1-4.

10. Chang C, Chang-Tesrn C, Yu-Ching T, Wei-Chin C (2000) A tissue culture protocol for propagation of a rare plant, Lilium speciosum Thunb. var gloriosoides Baker. Bot Bull Acad Sin 41: 139-142.

11. Reed BM, Sarasan V, Kane M, Bunn E, Pence VC (2011) Biodiversity conservation and conservation biotechnology tools. In Vitro Cell Dev Biol Plant 47(1): 1-4.

12. Northcutt C, Davies D, Gagliardo R, Bucalo K, Determann RO, et al. (2012) Germination In Vitro, Micropropagation, and Cryogenic Storage for Three Rare Pitcher Plants: Sarracenia oreophila (Kearney) Wherry (Federally Endangered), S. leucophylla Raf., and S. purpurea spp. venosa (Raf.) Wherry. HortScience 47(1): 74-80.

13. Reddy V (2017) Micropropagation of rare and threatened medicinal plant species of South Africa - for propagation and preservation: an overview. In: Beruto M, Ozudogru EA (Eds.), Proc. VI Int. Symp on Production and Establishment of Micropropagated Plants. Acta Hortic 1155: 619-624.

\section{Your next submission with Juniper Publishers will reach you the below assets}

- Quality Editorial service

- Swift Peer Review

- Reprints availability

- E-prints Service

- Manuscript Podcast for convenient understanding

- Global attainment for your research

- Manuscript accessibility in different formats

( Pdf, E-pub, Full Text, Audio)

- Unceasing customer service

Track the below URL for one-step submission https://juniperpublishers.com/online-submission.php 